\title{
Retailing in the United Kingdom - a synopsis
}

Steve Burt ${ }^{\dagger}$, Leigh Sparks ${ }^{\dagger \dagger}$ and Christoph Teller ${ }^{\dagger \dagger \dagger}$

Institute for Retail Studies, University of Stirling

†...Institute for Retail Studies, Stirling Management School, University of Stirling; FK9 4LA Stirling, Scotland, United Kingdom, Tel: + 44 (0) 1786 467399; Fax: + 44 (0) 1786 464745; E-Mail: s.l.burt@stir.ac.uk;

††...Institute for Retail Studies, Stirling Management School, University of Stirling; FK9 4LA Stirling, Scotland, United Kingdom, Tel: 44 (0) 1786 467386; Fax: + 44 (0) 1786 465290; E-Mail: leigh.sparks@stir.ac.uk

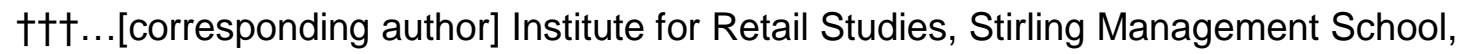
University of Stirling; FK9 4LA Stirling, Scotland, United Kingdom, Tel: +44 (0) 1786 46 6454; Fax: +44 (0) 178646 5290; E-Mail: christoph.teller@stir.ac.uk 


\section{Retailing in the United Kingdom - a synopsis}

\section{Abstract}

This paper illustrates the structure of, and trends in, the retail market of the United Kingdom (UK). This industry analysis describes the retail environment compared to continental Europe and considers the regulatory issues which have helped form this retail environment. By using secondary data we describe concentration and consolidation tendencies and explain specific features of the UK retail market. Major trends are identified and discussed, concluding with an outlook on future developments.

Keywords: United Kingdom, Retail Structure, Industry Analysis

\section{Introduction}

\subsection{Retailing in the United Kingdom and Europe}

In a number of ways retailing in the United Kingdom of Great Britain and Northern Ireland (in the following United Kingdom (UK)) appears to operate differently from the general pattern in continental Europe. Some may see this as yet another example of UK's unwillingness to embrace the European Union, but as with all retailing, the sector merely reflects the context within which it operates and the norms of behaviour that have developed in the domestic market. In this brief paper we highlight the distinctive features of the UK's retail market and illustrate how these have shaped the nature of competition in the sector.

Any attempt to understand the UK retail scene should start by recognising the distinctive features of this market (Mintel 2010). The United Kingdom is a compact island market of 60+ million people living in c25 million households and with the third highest density of population in Europe after Belgium and the Netherlands. It is the sixth largest economy (Gross domestic product EUR 1,808 billion) worldwide and third largest in Europe after Germany and France. The total consumer expenditures are the second highest in Europe (EUR 1,096 billion) after Germany (EUR 1,367) and $7^{\text {th }}$ highest per capita in Europe (EUR 17,851 in 2008). The UK is ranked $4^{\text {th }}$ in terms of total retail sales (EUR 318 billion) and $12^{\text {th }}$ in terms of retail sales per capita (EUR 5,184). Urban centres are relatively close together and although decentralisation 
of large retail stores to the urban periphery has occurred, planning policy has attempted to maintain a strong retail presence in the urban core of most major towns and cities (BCSC 2006, Guy 2007).

As occupants of mainland Europe know all too well, Britain can perhaps best be described as "in Europe, but not European"! General attitudes towards the European Union amongst the majority of the population can be described as ambivalent, as illustrated in the strong desire to retain the national currency. Despite this somewhat ethnocentric view, the UK market is an open economy, and a large number of non-national retailers operate in the market. At the same time, UK retailers are increasing their presence outside the domestic market.

\subsection{The Retail Environment in UK}

Government intervention in retailing has generally been directed at de-regulation and the pursuit of a free market economy. For example most restrictions on opening hours were removed in 1994; resale price maintenance in the book trade disappeared in 1995; and rules on pharmacy licensing were amended in 2004 . Where intervention has been restrictive, like elsewhere, it has primarily been in response to fears about the growing power of large operators. Store location in Britain is managed through zoning procedures in general land use planning policy i.e. it is the land use itself that receives the permission and not the user per se. From the mid 1990s there has been a clear emphasis on protecting and reviving town centres, rather than allowing further expansion on the periphery i.e. the so-called townb centres first' policy. Guy (2007) summarises retail land-use planning and regulation in the United Kingdom into four phases. Whilst the policy framework differs in timescale and to some degree in approach between the constituent countries/parts of the United Kingdom (Scotland, Wales, Northern Ireland and England), the broad dimensions of these four phases holds true across the constituent countries:

- 1960 s/1970s - early days of retail regulation with initial resistance to new retail forms e.g. out of town shopping centres, hypermarkets; 
- 1980 s - a loosening up of regulation to more approach a market led system allowing an expansion of new forms e.g. superstores, retail warehouses, regional shopping centres, outlet centres;

- 1990 s - the gradual tightening up of policy as cumulative effects from retail decentralisation on town centres became more noticeable e.g. the development of the 'town centres first' policy;

- 2000 s - the continuation of the 'town centres first' policy which has redirected offcentre developments to, and focus attention back on, town and city centres.

As can be noted from the brief policy descriptions of these phases, policy has tended to switch between restrictions on new forms of development to encouragement of such developments (as in the 'planning-free' Enterprise Zone experiment of the 1980s - see Dawson and Sparks 1982; Sparks 1987), and then back to more restriction. This switching of land-use policy has been driven essentially by the outcome of debates at particular times over the social versus economic requirements from retailing and the question of the degree of impact on existing retailers and existing centres (e.g. Guy 1998b; Guy and Bennison 2002). More recently these issues have been overlain with debates about the environmental impact and sustainability of various forms of retailing as for example in terms of productivity (e.g. Sparks 2005).

At the same time as there has been this policy regulation over land-use, there has also been periodic concerns about the continued growth of large retailers. These concerns have generally been couched in terms of competitive impacts of large retailers on smaller independent retailer operations and 'small shops' and on impacts on suppliers and producers of products, particularly in the food arena (e.g. Clarke 2000; Clarke et al. 2002). In the early 1980s, the decline of the small shop/independent retailer and the relationships between large retailers and suppliers were investigated by the Monopolies and Mergers Commission (MMC 1981). They found that whilst such concerns were justified, the evidence suggested that consumers were benefiting overall in terms of lower prices and as such there was no need to 
intervene in the market. This finding was confirmed in a follow-up study by the Office of Fair Trading (OFT 1985).

With the relaxation of restrictions on new retail forms in the 1980s, large retailers began to exploit a cycle of growth which saw considerable increases in scale and concentration. Existing large retailers continued to get bigger and concentration ratios continued to grow. In the early 1990s, academic concerns about abuses of market power began to be raised (e.g. Wrigley 1991, 1992a, 1992b, 1993) particularly in food retailing, and were picked up by the media particularly in terms of price comparisons with overseas markets. This price comparison issue was taken up by politicians, notably by the Labour Party, before and after its election success in 1997 (Sparks 2002). The basic claim was that the market had ceased to operate fairly and that large (food) retailers were making excess profits and abusing their market positions. Some of this perceived abuse was put down to individual 'greedy' firms, but there was also a concern over the operation of the market as a whole and the potential for collusion amongst companies. As power in food retailing continued to concentrate in the hands of a smaller number of retailers, so these concerns grew louder (e.g. Marsden et al 1998; Dobson and Waterson 1999; Dobson et al 2003), eventually focusing on the dominant position of Tesco (Burt and Sparks 2003). Whilst impact on town centres and small independent retailers has remained a topic of concern, the scale of the largest retailers, especially in food, has been seen as causing a competitive problem for the market as a whole.

The UK had in many ways in the 1980s had a more laissez-faire approach to retail development than elsewhere in Europe (Davies 1995; Guy 1998a). This came to an end in the early to mid 1990s when regulation was tightened primarily on the basis of competitive impact on town centres, the continuing growth of large retailers and the stirrings of environmental concern (e.g. BDP et al. 1992; CB Hillier Parker et al. 1998). Decentralisation of retailing as a consequence began to alter in form and to slow (see Schiller 1986, Hallsworth 1994; Wrigley 1994; Fernie 1998). The tightening of land-use regulation constrained development and altered the trajectory of retail development in the UK (Wrigley 
1994, 1998a, 1998b; Pal et al 2001; Guy 2002). This is not to say that the concerns over scale and impact have gone away. Indeed large retailers have proved adept at reacting to the new situations (e.g. Wood et al 2006; Thomas 2006; Guy and Bennison 2007). The continuing increases in concentration and corporate scale, and the ability of some retailers to continue to expand floorspace, have brought retailing, and especially food retailing, much closer attention from regulatory authorities. In particular there has been a sequence of investigations by the Competition Commission into the grocery market and its supplier relationships and competition (Sparks 2008a):

The culmination of the media and political campaign in the mid-1990s over retail prices was an investigation into supermarkets in 1999/2000 (Competition Commission 2000). The bid for Safeway by Morrisons in 2003 led to another investigation as competing bids for Safeway were all examined together (Competition Commission 2003). When Morrisons were permitted to buy Safeway (the other leading food retailers were not, on the basis of subsequent concentration levels), some stores had to be sold off due to concerns over local market shares, which produced a further report (Competition Commission 2005). Then in 2006 another full investigation into the market position in food retailing was announced as a consequence of continuing concerns (Competition Commission 2006, 2007a). Most recently, the Competition Commission has begun to investigate the proposed purchase of a single store by Tesco (Competition Commission 2007b). These investigations have generally found that the market is competitive but that some practices towards suppliers are not as good as they might be. As a consequence there are now proposals for a Grocery Ombudsman to regulate such relationships.

The context within which retailing in UK has developed is therefore as a relatively large and compact market, with close proximity of major urban centres; a traditional "inward looking" focus on developing the domestic market; and a relatively un-regulated legislative system allowing for operational flexibility. Whilst it is true that the restrictions have been greater in recent years, large firms have not really felt too constrained and new formats and developments have occurred in many towns and cities (e.g. Guy 2010). 


\section{Characteristics of the UK retail market}

Within this context, there are a number of distinctive features of the UK market which have influenced the evolution of the retail sector over the past twenty years. These provide an important contrast with the general pattern observed in mainland Europe.

\subsection{Size, structure and major players}

In the UK, the retail sector constitutes an important part of the economy, contributing $16 \%$ of GDP and is worth GBP 150 billion. It employs around 3 million people or 1 in 9 of the workforce and involves over 300,000 retail premises (see Figure ). Retail property dominates UK institutional investment, accounting for over half of the capital value of direct property assets held by institutions and property companies. The UK's retail sector is enormous and influential. It contains however massive contrasts. It is operated through many single shop entrepreneurial businesses, mobile shops and virtual shops. Retailing is a local affair with local demands: But some retailers are increasingly international and indeed 'global retail brands' such as Tesco. Retail sales are increasing although the number of outlets is falling and their format is changing. Low employee pay characterises much of the sector, but managerial pay is above average and all members of the Tesco main board receive over £2million pounds per annum.

As in other European retail markets the concentration tendency is quite remarkable. In the last ten years every third pound is generated by one of the five most powerful players in the market, i.e. Tesco, Sainsbury, Asda, Wm Morrison and Marks and Spencer (Mintel 2009/2010). Figure shows this increasing market concentration. 
Figure 1: Development of number of businesses, outlets and employment (2003-2007)

Source: based on Mintel (2010) and Mintel (2009)

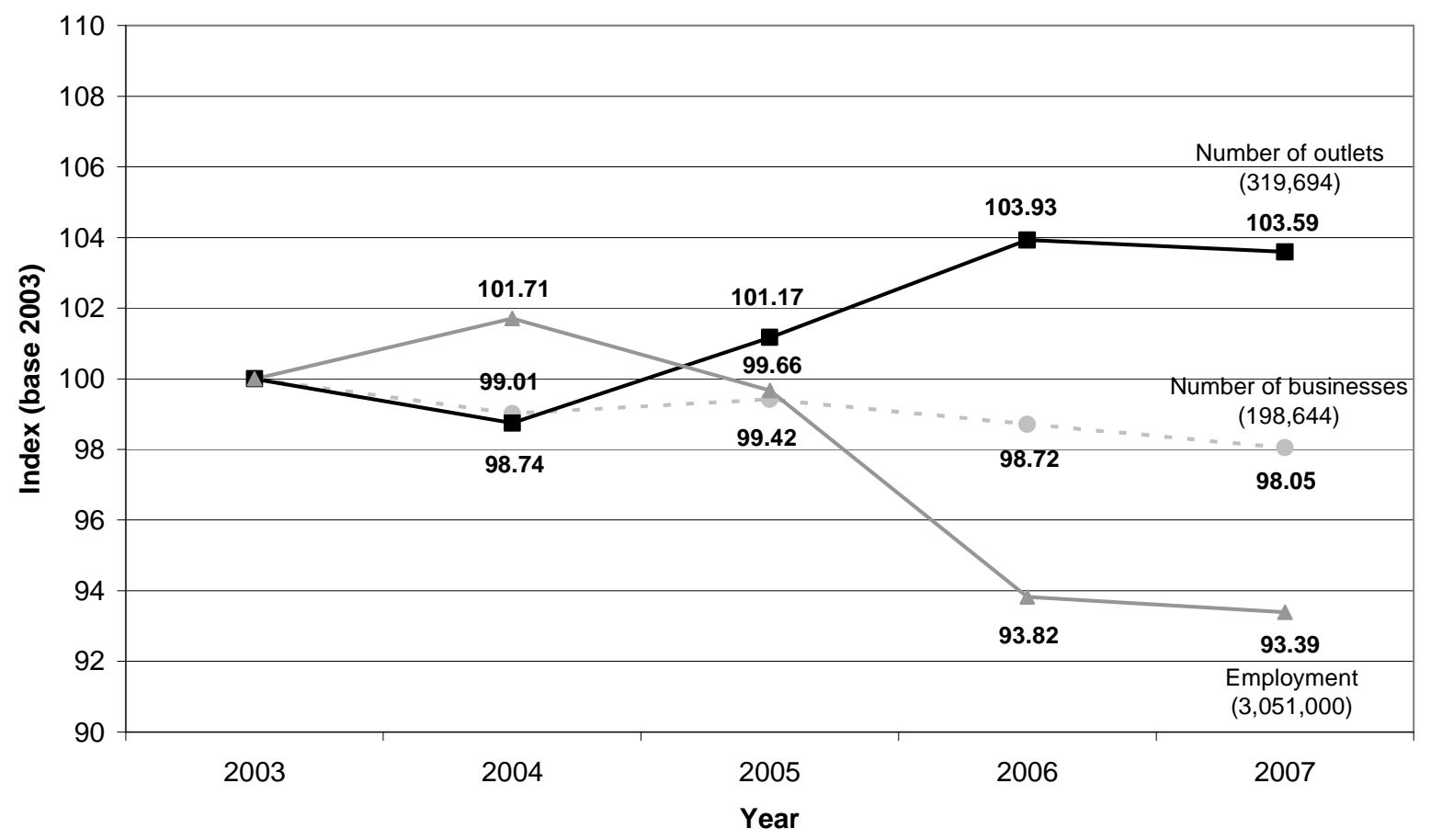

Figure 2: Sales of leading retailers

Source: based on Mintel (2010) and Mintel (2009)

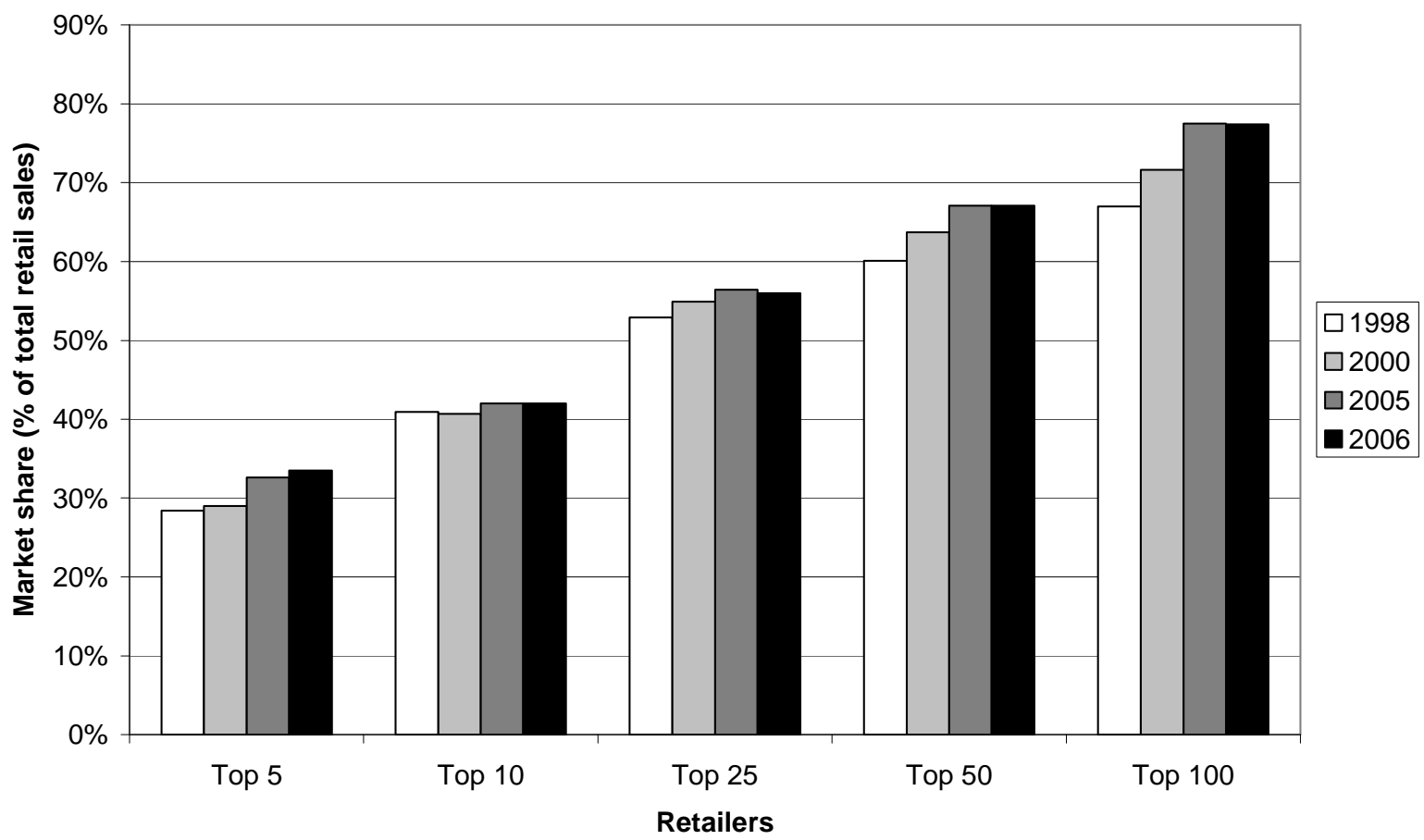


Parallel to this trend the number of businesses and the number of employees steadily decreases whereas the number of outlets rises gradually. As Figure 2 shows, a clear consolidation trend can be observed which is also representative for other European retail markets.

Table 1 and Table 2 provide overviews of the major players in the UK markets. The largest kind of businesses is food retailing in terms of outlet, sales, employees or capital expenditures. Whilst the leading players in each sector are mostly represented by UK retailers, some highly successful international retailers can be identified in all sectors, e.g Aldi (Germany), Primark (Ireland), IKEA (Sweden) or Amazon (United States).

Table 1: Major food retailers' operations in the UK

Source: Mintel 2010; Mintel 2009

\begin{tabular}{|c|c|c|c|}
\hline Retailer (parent/country of origin) & Operation(s) & outlets & 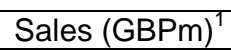 \\
\hline Tesco $^{2}$ & Multiple grocer & 2,272 & 38,191 \\
\hline Sainsbury's (J Sainsbury) & Multiple grocer & 792 & 18,911 \\
\hline Asda (Wal-mart, USA) & Multiple grocer & 356 & 18,004 \\
\hline Wm Morrison Supermarkets & Multiple grocer & 382 & 14,528 \\
\hline Co-operative Group (CWS/CRSc) (incl. Alldays) & Co-operative & 3,000 & 8,005 \\
\hline Marks \& Spencer (Food sales) & markets & 668 & 4,246 \\
\hline Waitrose (John Lewis Partnership & grocer & 197 & 3,940 \\
\hline Spar & Voluntary group & 2,544 & 2,770 \\
\hline Musgrave UK (Muscrave, Ireland) ${ }^{3}$ & $\begin{array}{l}\text { Multiple grocer, } \\
\text { convenience stores }\end{array}$ & 2,531 & 2,364 \\
\hline Aldi (Germany) & Discount grocer & 457 & 2,150 \\
\hline \multicolumn{4}{|c|}{$\begin{array}{l}\text { Caption: } 1 \text {, excl. sales tax; } 2 \text {, includes Tesco (Superstores): Supermarkets (448 outlets), Tesco Metro: } \\
\text { High street supermarkets ( } 174 \text { outlets), Tesco Express: Petrol forecourt (961 outlets), Tesco Extra: } \\
\text { Hypermarkets ( } 177 \text { outlets), One Stop Stores: Convenience stores ( } 512 \text { outlets); } 3 \text {, includes Budgens: } \\
\text { Multiple grocer, convenience stores ( } 183 \text { outlets), Londis: convenience stores (1,861 outlets), others: } \\
\text { Multiple grocer, convenience stores ( } 487 \text { outlets); }\end{array}$} \\
\hline
\end{tabular}


Table 2: Major non-food retailers operating in the UK

Source: based on Mintel (2010)

\begin{tabular}{|c|c|c|c|}
\hline Retailer (parent/country of origin) & Operation(s) & outlets & Sales $(\mathrm{GBPm})^{1}$ \\
\hline \multicolumn{4}{|l|}{ Major department and mixed goods retailers } \\
\hline Marks \& Spencer ${ }^{2}$ & Clothing, home goods and food & 668 & 8,164 \\
\hline Argos (Home Retail Group) & Catalogue showrooms & 730 & 4,281 \\
\hline John Lewis & Department stores & 27 & 2,327 \\
\hline Debenhams & Department stores & 149 & 1,839 \\
\hline Wilkinson & Variety stores & 308 & 1,364 \\
\hline \multicolumn{4}{|l|}{ Major clothing, textiles and footwear retailers } \\
\hline Marks \& Spencer (non-food) & Adult and children's clothing & 330 & 3,918 \\
\hline Next Retail ${ }^{3}$ & Adult and children's clothing & 510 & 2,198 \\
\hline Primark Stores (ABF, Irland) & Adult and children's clothing & 134 & 1,534 \\
\hline TK Maxx (TJX Companies, US) ${ }^{4}$ & Clothing and homewares & 218 & 1,497 \\
\hline Arcadia Group $^{5}$ & Adult clothing & 2,500 & 1,465 \\
\hline \multicolumn{4}{|c|}{ Major furniture, homewares and electrical goods retailers } \\
\hline DSGi $^{6}$ & Electricals, telecoms, computers & 680 & 3,903 \\
\hline Comet (Kesa Electricals) & Electricals/appliances & 250 & 1,660 \\
\hline The carphone Warehouse & mmunications & 850 & 1,385 \\
\hline IKEA (Sweden) & Furniture/household & 18 & 1,246 \\
\hline Vodaphone & Mobile phones & 350 & 830 \\
\hline \multicolumn{4}{|l|}{ Major DIY, hardware and garden products retailers } \\
\hline Kingfisher $^{\prime}$ & DIY superstores & 460 & 4,279 \\
\hline Homebase (Home Retail Group) & DIY superstores & 322 & 3800 \\
\hline Wickes/Tile Giant (Travis Perkins) & DIY superstores/tile specialists & 138 & 479 \\
\hline Focus & DIY superstores & 178 & 500 \\
\hline Garden Centres Group & Garden centres & 122 & 244 \\
\hline \multicolumn{4}{|c|}{ Major cultural, leisure and other non-food specialists } \\
\hline $\mathrm{HMV}^{8}$ & ideo games & 586 & 1,703 \\
\hline Game Group & ter games & 696 & 1,389 \\
\hline WH Smith & Books/news/stationary & 679 & 1,352 \\
\hline Sports Direct & Sports goods & 359 & 1,007 \\
\hline Halfords & Auto \& cycle accessories & 438 & 810 \\
\hline \multicolumn{4}{|l|}{ Major health and beauty retailers } \\
\hline Alliance Boots & ts/health/optical goods & 2,591 & 6,343 \\
\hline Lloyds Pharmacy Ltd (Celesio, Germany) & Pharmacies/health products & 1,715 & 2,150 \\
\hline Specsavers & Optical goods & 715 & 780 \\
\hline The Co-operative Pharmacy & Pharmacies & 800 & 745 \\
\hline AS Watson (Hutchinson Whampoa, Hong Kong) & Drugstores/pharmacies & 1,141 & 1,254 \\
\hline \multicolumn{4}{|l|}{ Mail order operators } \\
\hline Shop Direct Group & UK home shopping & & 1,796 \\
\hline Amazon (US) & Online retailer & & 955 \\
\hline Next Directory (Next) & Clothing \& household goods & & 816 \\
\hline N Brown & Clothing for older customers & & 611 \\
\hline Grattan/Freemans (Otto Group, Germany) & General catalogue & & 575 \\
\hline \multicolumn{4}{|c|}{$\begin{array}{l}\text { Caption: 1, excl. sales tax; } 2 \text {, total UK sales; 3, does not include Directory sales; } 4 \text {, Sales include turnover from } \\
\text { stores in Ireland and Germany; } 5 \text {, includes turnover from overseas stores and is for a } 66 \text { week period due to a } \\
\text { change of year end; } 6 \text {, including Currys ( } 519 \text { outlets; sales: GBPm 2,658), PC World (161 outlets; sales GBPm } \\
1,245) ; 7 \text {, including B\&Q (DIY superstores, } 322 \text { outlets, sales GBPm 3,800), Screwfix (DIY stores, } 138 \text { outlets, } \\
\text { sales GBPm 479); 8, HMV (Music/video goods, } 272 \text { stores, sales GBPm 314), Waterstone's (bookstores, } 314 \\
\text { outlets, sales GBPm 548); 9, Superdrug (Drugstores, pharmacies, } 900 \text { outlets, sales GBPm 1,074); Savers } \\
\text { Health \& Beauty (Drugstores, } 241 \text { outlets, sales GBPm 180) }\end{array}$} \\
\hline
\end{tabular}

\subsection{Sustained and steady growth in retail sales volume}

Over the past twenty years, the UK retail sector has operated and evolved in a market exhibiting sustained growth in retail sales volume. UK retail sales emerged strongly from the 1989-1992 recession, reinforcing a similar strong pattern of growth in the 1980s. The 
availability of consumer credit is cited as the driving force behind this sales growth, allowing customers to take advantage of the changing retail offer made available by shorter market lead times, more fashion cycles and the improved merchandising and marketing activities of retailers. Whatever the driving force behind these trends, unlike most of mainland Europe over this period, most retail sectors in the UK evolved against a background of steady and sustained growth in retail sales volume (see Table 3). Most recently however the 'credit crunch recession' of 2008 onwards has seen retail sales fall and stagnate and many businesses close shops or shut down totally (e.g. Woolworths).

Table 3: Retail sales (2004-2008)

Source: adapted from Mintel (2010)

\begin{tabular}{|c|c|c|c|c|c|c|}
\hline Year & 2004 & 2005 & 2006 & 2007 & 2008 & $\begin{array}{l}\text { Change } \\
2004-08\end{array}$ \\
\hline All retailers (GBP million) & 228,981 & 231,699 & 238,008 & 247,151 & 254,652 & $+11.2 \%$ \\
\hline \multicolumn{7}{|l|}{ Sector } \\
\hline Food $^{1}$ & 100,349 & 103,744 & 107,640 & 112,244 & 118,914 & $+18.5 \%$ \\
\hline Mixed goods & 19,834 & 19,775 & 20,348 & 21,120 & 20,566 & $+3.7 \%$ \\
\hline Clothing, footwear and textiles ${ }^{2}$ & 30,805 & 31,073 & 32,504 & 33,372 & 33,273 & $+8.0 \%$ \\
\hline Household goods ${ }^{3}$ & 29,554 & 28,582 & 28,811 & 29,811 & 28,925 & $-2.1 \%$ \\
\hline Others $^{4}$ & 33,027 & 33,129 & 33,281 & 34,315 & 35,672 & $+8.0 \%$ \\
\hline Health and beauty & 3,749 & 3,837 & 3,703 & 3,922 & 4,137 & $+10.3 \%$ \\
\hline Non-store & 11,663 & 11,559 & 11,720 & 12,368 & 13,165 & $+12.9 \%$ \\
\hline \multicolumn{7}{|c|}{$\begin{array}{l}\text { Notions: } 1 \text {, includes: grocers, large, small, off-licences and others; } 2 \text {, includes household textiles, clothing, large } \\
\text { chains, smaller operators, footwear; } 3 \text {, includes: furniture, electricals and DIY; } 4 \text {, Books, carpets, photographic } \\
\text { etc. and other specialists; } 5 \text {, includes mail orders and others } \\
\text { Source: adapted from Mintel } 2010\end{array}$} \\
\hline
\end{tabular}

\subsection{Stock market ownership}

Although the last few years has seen a number of high street clothing retailers move into private ownership, the majority of UK retailers have a long history of raising finance on capital markets. The involvement of external stakeholders in this way places increased pressure on management, and focuses attention on financial measures of performance. The problems of retail icons such as Marks and Spencer and J Sainsbury in the mid1990s and 200s respectively, and the fate of senior managers at these companies, illustrate the power of the "city" and institutional shareholders in monitoring performance and raising expectations as critical stakeholders. A further implication of a listing on the stock exchange is that it makes companies vulnerable to takeover (at the right price) and contested acquisitions are not uncommon as companies seek to grow market share. Tesco in the 2000s grew its 
convenience market share through acquisitions, Wal-Mart was able to snatch Asda from an agreed deal with Kingfisher in 1997 and the Morrisons/Safeway merger of 2003 only came about after a Competition Commission investigation as to which company should be allowed to buy Safeway amongst all the leading food retailers.

\subsection{Cost structures}

A cursory glance at the financial accounts of UK retailers (particularly grocery retailers) suggests that the market generates high net margins. However, direct comparison with similar companies in mainland Europe is dangerous as differences in financial accounting procedures, especially in the treatment of items such as depreciation and goodwill distorts direct comparisons. Cost structures within UK retailing are however different and as such influence operating policies and behaviour. Property and labour cost structures illustrate some of these differences. Land and store fitting out costs are high, and shop rents are not linked to turnover, but often to regular Upward Only Rent Reviews, which means that rental charges generally increase irrespective of market performance (although the recent recession has challenged this approach). Labour cost structures are also different, not necessarily in respect of the overall cost of labour, but in the management of labour. Parttime labour is the dominant form of shop-floor employment in Britain. Nearly $60 \%$ of all retail employees are part-time, and $64 \%$ are female $-70 \%$ of whom work on a part-time basis. This provides opportunities for cost savings in some of the social costs of labour, but more importantly it allows a high degree of labour flexibility providing retailers with considerable scope to match labour with peak periods of activity, and thus improving labour efficiency. Reynolds et al. (2005) show how such differences feed into aspects of international productivity and other comparisons.

\subsection{Internationalisation}

UK retailers are involved in global sourcing and retailing activities. The global success of UK retailers is enhanced by a positive retail environment within the UK. Table 4 shows that almost every retail sector contains a powerful international player based in UK. 
Table 4: Major UK retailers with foreign operations

Source: Mintel (2010)

\begin{tabular}{|c|c|c|c|c|}
\hline $\begin{array}{l}\text { Retailer } \\
\text { (Parent) }\end{array}$ & Operations & Foreign markets & $\begin{array}{l}\text { Worldwide sales } \\
\text { (GBP billion) }\end{array}$ & $\begin{array}{l}\% \text { from } \\
\text { abroad }\end{array}$ \\
\hline Tesco & Grocery & $\begin{array}{l}\text { Malaysia, South Korea, Japan, Thailand, China, } \\
\text { Czeck Republic, Slovakia, Hungary, Poland, } \\
\text { Ireland, Turkey, United States }\end{array}$ & 54.3 & 29.7 \\
\hline Kingfisher & DIY & $\begin{array}{l}\text { Poland, China, Ireland, Italy, Taiwan, France, } \\
\text { Sain, Turkey, Germany }\end{array}$ & 10.0 & 57.0 \\
\hline $\begin{array}{l}\text { Marks \& } \\
\text { Spencer }\end{array}$ & $\begin{array}{l}\text { Mixed goods \& } \\
\text { grocery }\end{array}$ & North America, Far East, Ireland & 9.1 & 10.0 \\
\hline DSGi & Electricals & $\begin{array}{l}\text { Denmark, Sweden, Norway, Finland, Iceland, } \\
\text { Italy, Spain, Czech Republic, Greece, Ireland, } \\
\text { Hungary }\end{array}$ & 8.1 & 48.1 \\
\hline Alliance Boots & $\begin{array}{l}\text { Health \& } \\
\text { beauty }\end{array}$ & Japan, Netherlands, Taiwan, Thailand, Ireland & 7.1 & 11.3 \\
\hline $\begin{array}{l}\text { Kesa } \\
\text { Electricals }\end{array}$ & Electricals & $\begin{array}{l}\text { Belgium, Netherlands, France, Czech Republic, } \\
\text { Slovakia }\end{array}$ & 5.0 & 66 \\
\hline Next & $\begin{array}{l}\text { Clothing \& mail } \\
\text { order }\end{array}$ & Europe, Middle \& Far East & 3.3 & 9.1 \\
\hline Signet & Jewellery & USA & 2.3 & 76 \\
\hline $\begin{array}{l}\text { The Carphone } \\
\text { Warehouse }\end{array}$ & $\begin{array}{l}\text { Tele- } \\
\text { communication }\end{array}$ & $\begin{array}{l}\text { France, Germany, Poland, Ireland, Switzerland, } \\
\text { Netherlands, Portugal, Sweden, Spain, Czech } \\
\text { Republic }\end{array}$ & 2.1 & 33.3 \\
\hline HMW Group & $\begin{array}{l}\text { Music, videos } \\
\& \text { books }\end{array}$ & Canada, Ireland, Hong Kong, Singapore, Japan & 2.0 & 12.7 \\
\hline
\end{tabular}

The arguably most successful retailer in UK - Tesco - can serve as a show case of successful internationalisation of UK retailers (see Figure 1). Tesco has turned from a company dominated by UK food superstore retailing to one where the sales floor space outside the UK is greater than that inside the UK, store number growth is focused internationally and profit and turnover growth is faster internationally than in the UK (Seth and Randall 2005). 
Figure 1: Tesco Sales 1961-2007

Source: Sparks (2008a)

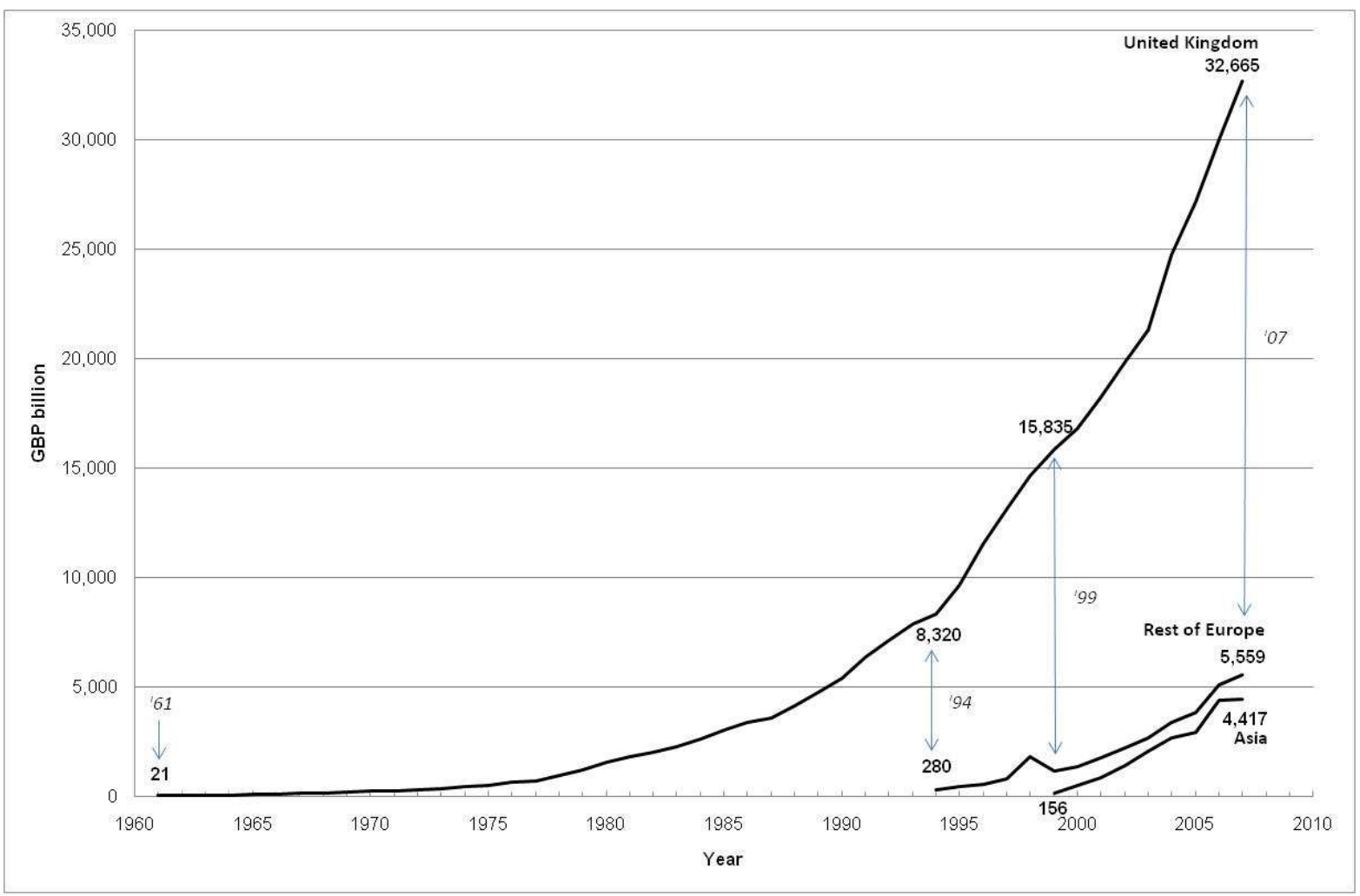

However, it needs to be noted that internationalisation is not always easy and successful. Indeed failures and market exits are suprisingly common (Burt et al. 2004), even with high profile UK retailers. E.g., Marks \& Spencer endured a torrid exit from various markets in the early 2000s (Burt et al. 2002).

\subsection{Loyalty card schemes}

There are large loyalty card schemes across the UK. Boots the Chemist's Advantage Card has almost 15 million active cardholders and is used in 70 per cent of sales transactions in the company. The Tesco Clubcard scheme (Humby et al. 2003) has probably 13 million members and has been credited with helping the retailer reach its current dominant market position. The information received on purchase patterns has been vital in adjusting the product, store and other offers and in targeted and micro-marketing activities. The data to some extent is the heart of the business strategy. 
Other retailers have not been so convinced be the idea or practice of loyalty cards. Their argument is that it is an expensive way to learn about consumer behaviour, provides only partial data and does not really engender loyalty per se. Businesses such as Sainsbury, Asda and the Co-operative Group have at different times switched their views on the value of such schemes.

The evidence however would seem to point to loyalty schemes being successful when managed and integrated fully with the business. The consumer focus that a loyalty scheme can bring, allows retailers to track mobile consumers as they shop in different ways across the company. Thus for example as Tesco have developed their various formats and channels (e.g., Metro, Express, Extra, Direct, Homeplus, Telecoms, etc.; see Table 5) so the Clubcard can be used as the connective mechanism to track consumers and their patterns of shopping. Such data, whilst somewhat problematic in both privacy and practical terms at the individual level (e.g., Smith and Sparks 2004) does allow a strong degree of segmentation and a fuller understanding of actual and potential behaviours. It also allows store specific and individualised merchandising and marketing.

\section{The nature of competition}

Faced until recently with an operating environment with natural growth in retail sales, fuelled in part by consumer credit and a consumer willing to spend; strict taskmasters in the form of city investors requiring continued growth, financial performance and returns on investment; and cost structures allowing a service based focus in the retail offer, the nature of competition in the UK market has taken a particular form, with a strong emphasis on nonprice based competition, and control and replication of a branded retail offer. 


\subsection{Centralised management and procedures}

Management systems and operating procedures in UK retailing are highly centralised. This reflects investment in technology based control systems to improve efficiency and control costs, but also a management philosophy based upon control and conformity. Localised merchandising and marketing activities do take place, but these are company managed and supported rather than the outcome of store level entrepreneurial activity. One example of centralised management systems providing scope for operational efficiencies, cost savings, and general improvements in quality standards and service levels is the investments made by UK grocery retailers in managing the supply chain - initially through the adoption of centralised distribution systems and third party distribution services, and latterly through EDI and ECR initiatives. 
Figure 2 provides the example of the impact upon Tesco's inventory levels over this period. The 1960 s to 1980 s were characterised by manufacturer organised direct to store deliveries. Retailer controlled centralisation and composite centre development in the 1980s produced major costs savings and service benefits. Recent complications to the business e.g. global operations, internet sales, non-food growth, catalogue sales, have added complexity, but the operation continues to be world leading (Smith and Sparks 2009). In a broader context, the strong central control exercised over operations also provides corporate discipline and uniformity in the customer offer. A consistency which has enhances the potential to develop strong private brand ranges 
Figure 2: Tesco - Inventory Levels 1961-2007

Source: Sparks (2008a)

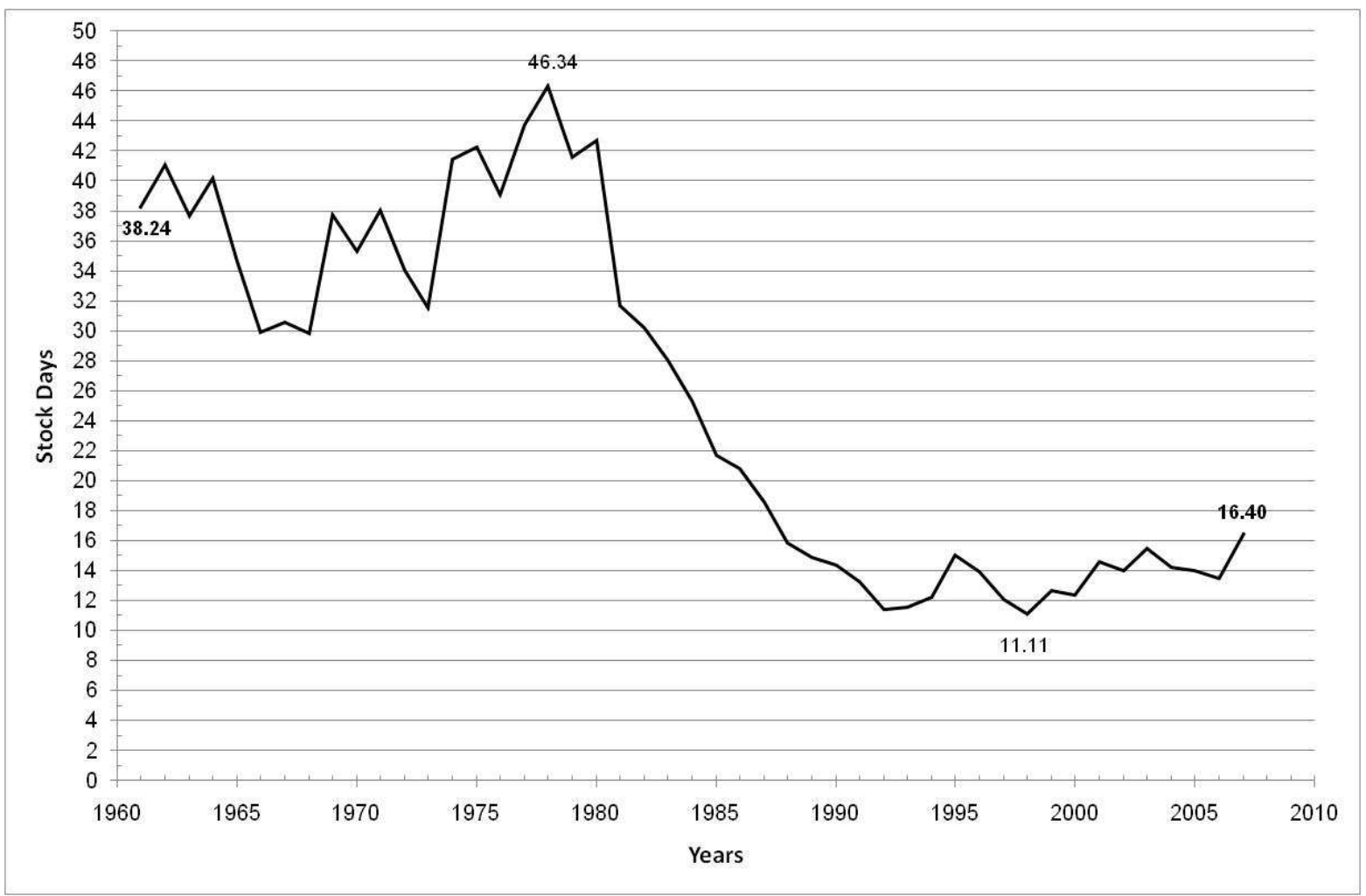

\subsection{Channel leadership}

Concentration at the level of the firm has occurred in every retail sector. The growth of retail power in the channel is a universal phenomenon, but the way that this power is used differs from market to market. In Britain, market power, and information power provided via scanning and EPOS systems has been used not just to improve trading terms with suppliers but in a proactive way to manage and develop product categories. This does not mean that retailers have not sought improved terms, but there has also been an emphasis on growing channel margin not just taking a larger share of channel margin. Reductions in payment delays (typically under 28 days in grocery), investments in supplier capabilities and supply chain efficiencies, and more intense developmental cooperation with a reduced number of key suppliers, characterise this way of operating. Leading retailers now talk of a demand rather than supply channel, which reflects the emphasis on responding to customers and 
providing innovation in products and services, rather than supplying existing products and services.

\subsection{Specialised format development}

With a few exceptions, there has been less cross-product market diversification in Britain than in mainland Europe, with the major chains inclined to focus on their core business activity. This is also seen in the tendency to develop "specialised" formats rather than multiline generalist formats. Although product range extensions are now starting to blur these clean distinctions, historically the UK market has evolved with specialist retailers serving specific segments. This is perhaps most evident in the grocery sector. Until relatively recently, all the major grocery retailers were effectively developing and operating a single format - the superstore. Britain did not have any true hypermarkets in the continental sense. This trend towards "specialisation" further embraced an operating approach based on quality environments, merchandising and service rather than price. Tesco serves as an illustrative example of this 'specialised format development' (see Table 5). The development of Tesco Metro and Tesco Express stores in the early 1990s were the first steps to focus on the urban centre and convenience customers. The 1980s had been almost entirely focused on developing out-of-town superstores, but this approach was limiting in terms of the types of shopping trips that could be serviced. By re-entering high streets and locating Tesco Express stores as convenience outlets often on petrol forecourts, Tesco began to capture those other shopping trips both from new and existing customers. As UK land-use planning tightened to reduce out-of-town opportunities so these different formats and locational types became more important (Wood et al. 2006). 
Table 5: Tesco's format development in the United Kingdom

Source: Sparks (2008b)

\begin{tabular}{|c|c|c|c|c|}
\hline Format/Formula & $\begin{array}{l}\text { Opening } \\
\text { Year }\end{array}$ & Description & $\begin{array}{l}\text { Number of } \\
\text { stores }\end{array}$ & $\begin{array}{l}\text { Store Floorspace } \\
\text { (000 sq.ft) }\end{array}$ \\
\hline $\begin{array}{l}\text { Hypermarket } \\
\text { (Tesco Extra) }\end{array}$ & 1996 & $\begin{array}{l}\text { Stores over c60K sq. ft. sales, offering food } \\
\text { and non-food, often using mezzanine floors }\end{array}$ & 147 & 10,252 \\
\hline $\begin{array}{l}\text { Superstore } \\
\text { (Tesco) }\end{array}$ & $\mathrm{n} / \mathrm{a}$ & $\begin{array}{l}\text { Specialist food stores with some non-food, } \\
\text { varying from c20-45K sq.ft }\end{array}$ & 433 & 13,212 \\
\hline $\begin{array}{l}\text { City Supermarket } \\
\text { (Tesco Metro) }\end{array}$ & 1992 & $\begin{array}{l}\text { Food specialists with extensive ranges of } \\
\text { convenience foods, mainly high street } \\
\text { locations }\end{array}$ & 162 & 1,906 \\
\hline $\begin{array}{l}\text { Convenience } \\
\text { Store } \\
\text { (Tesco Express) }\end{array}$ & 1995 & $\begin{array}{l}\text { Convenience focused stores in varying } \\
\text { locations, but many on petrol station } \\
\text { forecourts. Additionally has c500 One Stop } \\
\text { convenience stores left over from takeover } \\
\text { in } 2002 \text {. }\end{array}$ & 735 & 1,562 \\
\hline $\begin{array}{l}\text { E-retailing } \\
\text { (Tesco.com) }\end{array}$ & 1999 & $\begin{array}{l}\text { Internet ordering, store-based picking } \\
\text { model covering most of the UK. Original } \\
\text { trial from } 1997 .\end{array}$ & & \\
\hline $\begin{array}{l}\text { Catalogue retailing } \\
\text { (Tesco Direct) }\end{array}$ & 2006 & $\begin{array}{l}\text { Catalogue available in store for ordering } \\
\text { over the web, phone or in store, expanded } \\
\text { in second issue to } 10 \mathrm{~K} \text { products. Delivery } \\
\text { direct to home or via collect at store. }\end{array}$ & & \\
\hline $\begin{array}{l}\text { Non-food Stores } \\
\text { (Tesco Homeplus) }\end{array}$ & 2005 & $\begin{array}{l}\text { Stores of c } 30 \mathrm{~K} \text { sq } \mathrm{ft} \text { offering wide range of } \\
\text { non-food items }\end{array}$ & 5 & 175 \\
\hline
\end{tabular}

Overall in grocery this development also encouraged in-store segmentation (via private brand) rather than format based segmentation. In non-food markets, high street based fashion retailers similarly focused their offer, but in this case specialisation took the form of branded store offers aimed at distinctive consumer segments.

\subsection{Retailer Brands}

A distinctive feature of UK retailing, particularly grocery retailing, is the nature of and role played by private brand ranges. UK retailers have used the private brand concept not simply as a price tool but to build and develop consumer trust and to portray the retail company as the innovator and guarantor of product quality. As grocery retailers have taken a larger share of the market and assumed channel leadership, they have used their increased power not to extract further margin from suppliers but to grow product categories and enact a demand chain approach - albeit under the retailer's brand name. In the grocery market around 39\% of sales are through private brand ranges, although this varies by product group. 
The clarity, consistency and performance of the retail offer allowed by strong centralised management control has allowed retailers to adopt a marketing orientation to activities and start to unlock the value in the retail brand name. The role of innovation and product packaging in conveying brand trust has been understood, and retailers have taken a holistic view of retail branding linking the corporate, store and product brand and recognising the potential to become brands in their own right. The importance of the store in creating and projecting brand identity for retailers has been recognised. From the traditional private label (low price copy-cat product) position in the late 1970s and early 1980s, retailers have managed product choice, shelf allocation and pricing policies within their stores to reposition the private label as a retailer brand - this has seen a change in the private brand offer from low quality to superior quality; from low price to competitive price; from me-too (copy) products to new innovative products; and from an alternative product to an alternative brand (Burt 2000). Most grocery retailers now offer a range of private brand options supported by segmented product options aimed at specific customer needs as shown in Table 6.

\section{Table 6: Segmented private brand range of leading grocery chains}

\begin{tabular}{llll}
\hline & Grocery Chain & \\
Market Segment & Tesco & Sainsbury & ASDA \\
\hline Exclusive Premium & Finest* $^{*}$ & Taste the Difference & Extra Special \\
Standard & Tesco & Sainsbury & Asda \\
ValuelBudget & Value & Basics & Smart Price \\
Healthy Eating & Healthy Lving & Be Good to Yourself & Good For You \\
Organic & Organic & SO Organic & Simple Organic \\
Childrens & Kids Healthy & Kids & Great Stuff \\
Other & Free From & Free From & Go Cook \\
& Whole Foods & Just Cook & Classics \\
& Naturally & Active:Naturals & Fresh Tastes \\
\hline
\end{tabular}

The recent recession has seen a stronger interest in price and thus in retail brand options, especially in food. Even high-end retailer Waitrose has introduced an Essentials retailer brand to strong effect, and Tesco has produced a range of discounter brands to compete against Aldi and Lidl especially. 


\subsection{Store vs. non-store retailing}

In the run-up to 2000 there was both spectacular hype and then the equally spectacular fall of many internet or 'e' retail operations. Both the hype and the fall were probably overdone. Profitable Internet retailers exist and the sector continues to develop strongly. Two of the most visited UK retail Internet sites are Tesco and Argos, both of whom have added eretailing to their existing channels of operations, enabling them to increase their product and customer range. Some specialist operators, including quite small and local businesses, are doing well e.g. Asos.com. The movement of Dixons to become an Internet-only operation is another signifier of the expansion and acceptance of the channel. Indeed many retailers would now describe themselves as multi-channel. Whilst there seems to be an appetite in the UK for the Internet as a shopping medium, the true extent to which it will eventually challenge or complement existing retailing remains open to question.

One of the reasons why the impact of e-retailing is as yet undecided is that there remain issues about the form and functions that need to be performed and the costs of these. Some begun by developing pure Internet-based operations on the back of existing activities, but with specialist picking facilities (e.g. Sainsbury). Tesco however chose to add the Internet channel to their existing store-based operation and to initially focus picking of orders and delivery from local stores. With the expanded ranges now provided online, they now also use their distribution network for picking and delivery of non-store carried products. These different models may be suitable in different circumstances, though concern in all cases remains about the mechanistics of delivery and whether huge volumes of home delivery is actually economically or environmentally desirable (Foresight Retail Logistics Task Force 2000). Sainsbury eventually moved to a store-based picking operation, but recently Tesco have begun to operate internet-only stores in urban areas of high internet sales volumes and density.

The Internet is becoming a factor of shopping and retailing in the UK. Internet retail sales in the UK according to Mintel (2008) reached GBP 12.7 billion in 2007 and had thereby 
increased by $33 \%$ from 2006. Between 2003 and 2007 the increase of sales was $220 \%$ mainly driven by (1) the above mentioned multi channel strategy of Tesco and Argos, (2) the growth of Internet-only retailers, e.g. multi-award winning Asos.com (3) the rising preference by digitalised products and the online sales of other distance retail businesses like mail order provider (Mintel 2008; see

Figure 3).

Figure 3: UK Online retail sales

Source: Mintel (2008)

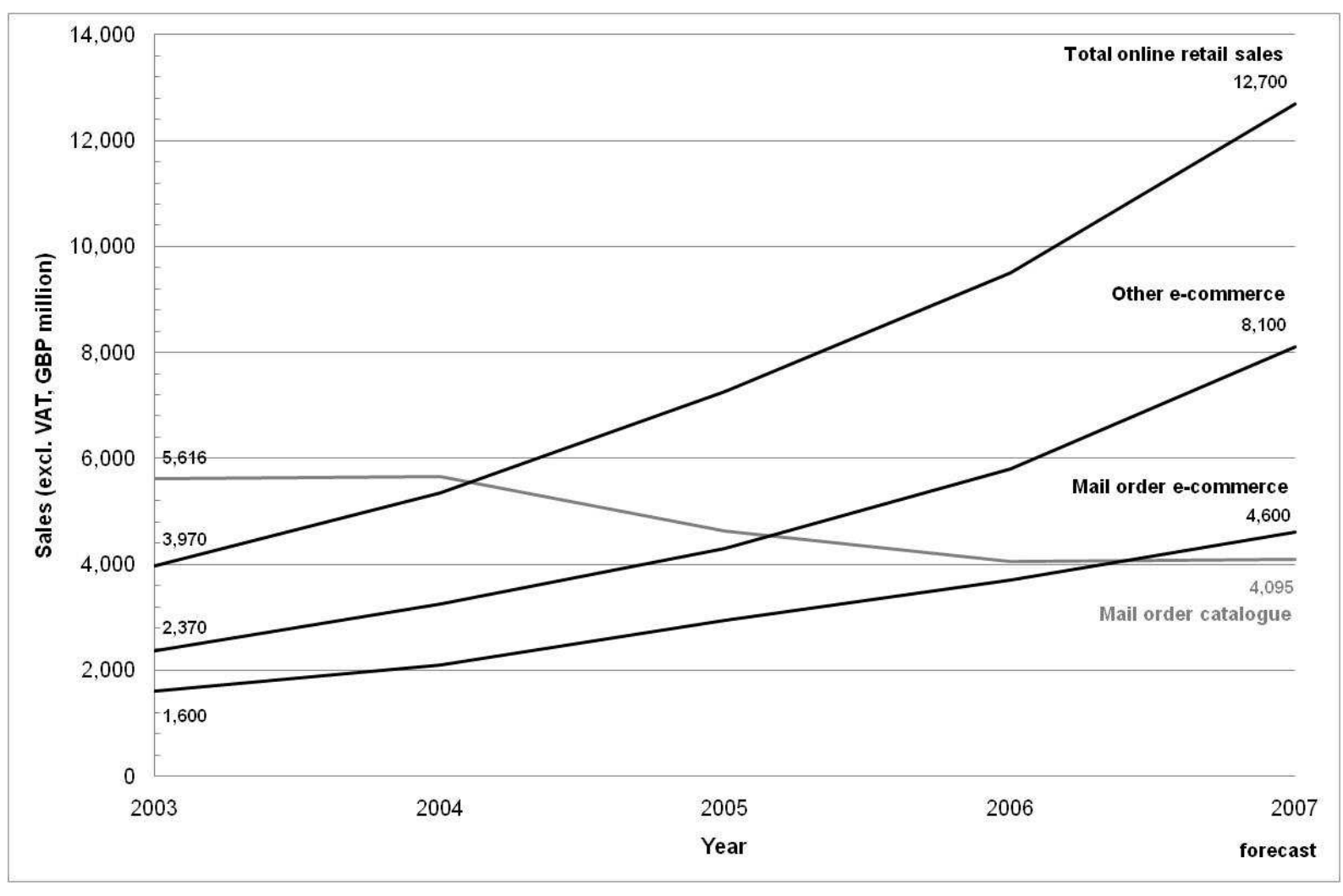

Nevertheless, it should not be forgotten the increase rate is to be interpreted with respect to the low online sales level in 2003. Furthermore, the online sales for 2007 are only $5.1 \%$ of the total retail sales (compare also with Table 3). Nonetheless the internet market continues to grow and evolve into a recognisable channel of retail operations. 


\section{Outlook}

The UK retail market has generally evolved with an emphasis upon service based non-price competition over the past twenty years. Certain features of the UK market have encouraged - or at least not hindered - this approach. The major challenge over the past few years has been how to incorporate a more price sensitive focus within the retail offer, particularly after the onset of the credit crunch recession. The price issue has come to the fore in a number of ways. The arrival of discounters (Aldi, Lidl, Netto, Costco and Wal-Mart) in the 1990s drew attention to pricing and margin strategies of grocery retailers. This compounded the underlying feeling of price disparities with continental Europe and North America from the experiences of customers visiting these markets (a perception compounded by the strength of the pound), and a press campaign based on the "rip off Britain" theme. Whilst Aldi and Lidl have done well in the recession in the UK, there remains UK suspicion over aspects of pricing and the relationship of low price to low quality. In food this has been based around both issues of food safety and scares e.g. BSE, but also increasingly about concerns over environmental welfare. In non-food however fast fashion and price based retailers such as Primark, New Look, Top Shop etc have been hugely successful, with little concern shown by the public over sourcing issues.

Retailers in all sectors have responded, and government statistics show retail price deflation in most product markets. In the grocery sector a blurring of product lines has occurred as fast moving (and higher margin) key non-food lines are added to the offer to maintain performance whilst grocery prices are adjusted. In non-food, sourcing from low cost countries has increased, and fast fashion principles have been embraced. The challenge however, is that the UK consumer has become accustomed to a retail sector offering quality shopping environments and high service levels and will expect these to be maintained whilst prices are reduced. This must be achieved in a system with relatively high cost structures. As always the best retailers will adjust and prosper, but it is evident that some previously lauded as market leaders eg Marks and Spencer and Sainsbury have found the transition much more painful. 
Retailing in the UK is thus a successful and a significant sector of the economy. It contains major corporate and co-operative entities. The impact of these large businesses is perhaps the main concern currently in regulatory terms, as aspects of their power are seen negatively by some consumer groups, sections of the media and some suppliers. Whilst there is a rising concern to ensure retail diversity, there is as yet no consensus on what this means and how to achieve it. For some, even the evidence is unclear (Wrigley et al. 2009), whereas for others supposed remedies to local competition are simply recipes for further concentration (Hughes et al. 2009).

An interesting development in recent years however, and symptomatic of the scale and potential role of retailers, has been the attempt by government to capture their assistance in changing consumer behaviours. There has been enacted regulation on control of smoking displays, alcohol sales and descriptions of product contents e.g. healthy living. Government is seeing large retailers as potent forces in combating some of the health problems of consumer society. Some might see this as odd, blaming the retailers for the problems in the first place, but government is increasingly realising that getting large retailers to work for positive ends could bring big benefits. Retailers are thus seen as a social force.

At the other end of the scale spectrum, though linked in a topic sense, there has been a major revival of local production and sales. Famers' markets have expanded enormously in number and local community focused stores and farm shops have added to the range of store choices. Increasing concern with traceability, sustainability and localisation of food promises to be a recurring theme in food retailing in the coming years. 


\section{References}

BCSC (British Concil of Shopping Centres) (2006): Future of Retail Property. Changing Demographics and Consumer Patterns. London: BCSC.

BDP Planning and Oxford Institute of Retail Management (1992): The Effects of Major Out of Town Retail Development: A Literature Review for the Department of the Environment, London: HMSO.

Burt S. (2000): The Strategic Role of Retailer Brands in British Grocery Retailing, in: European Journal of Marketing, Vol. 34 No 8, pp. 875-890.

Burt, S.L.; Sparks, L. (2003): Power and Competition in the UK Retail Grocery Market, in; British Journal of Management, Vol. 14, No 3, pp. 237-254.

Burt, S.L.; Dawson, J.A.; Sparks, L. (2004): The international divestment activities of European grocery retailers, in: European Management Journal, Vol. 22, No 5, pp. 483492.

Burt, S.L.; Mellahi, K.; Jackson, T.P.; Sparks, L. (2002): Retail internationalisation and retail failuer: issues from the case of Marks and Spencer, International Review of Retail, Distribution and Consumer Research, Vol. 12, No 2, pp. 191-219.

CB Hillier Parker and Savell Bird Axon (1998): The Impact of Large Foodstores on Market Towns and District Centres, Report for the Department of Environment, Transport and the Regions, London: TSO.

Clarke, I. (2000): Retail power, competition and local consumer choice in the UK grocery sector, in: European Journal of Marketing, Vol. 34, No 8, pp. 975-1002.

Clarke, R.; Davies, S.; Dobson, P.; Waterson, M. (2002): Buyer Power and Competition in European Food Retailing, Cheltenham: Edward Elgar.

Competition Commission (2000): Supermarkets: A report on the supply of groceries from multiple stores in the United Kingdom, London: TSO, online: http://www.competitioncommission.org.uk/inquiries/completed/2000/index.htm.

Competition Commission (2003): Safeway plc and Asda Group Limited (owned by Wal-Mart Stores Inc); Wm Morrison Supermarkets plc; J Sainsbury plc; and Tesco plc: A report 
on the mergers in contemplation, London: TSO, online: http://www.competitioncommission.org.uk/inquiries/completed/2003/safeway/index.htm.

Competition Commission (2005): Somerfield plc/Wm Morrison Supermarkets plc. A report on the acquisition by Somerfield plc of 115 stores from Wm Morrison. London: TSO. online: http://www.competitioncommission.org.uk/inquiries/ref2005/somerfield/index.htm.

Competition Commission (2006): Groceries Market Investigation: Issues Statement. London: TSO, online: http://www.competitioncommission.org.uk/inquiries/ref2006/grocery/index.htm.

Competition Commission (2007a): Groceries Market Investigation: Emerging Thinking London: TSO, online: http://www.competitioncommission.org.uk/inquiries/ref2006/grocery/index.htm.

Competition Commission (2007b): Tesco/Co-op store acquisition in Slough. London: TSO, online:http://www.competition-commission.org.uk/inquiries/ref2007/tesco/index.htm.

Davies, R.L. (ed.) (1979): Retail Planning in the European Community, Farnborough: Saxon House.

Davies, R.L. (ed.) (1995): Retail Planning Policies in Western Europe, London: Routledge.

Dawson, J.A.; Sparks, L. (1982): Retailing Developments and Enterprise Zones, in: International Journal of Retail and Distribution Management, Vol. 10 No 1, pp. 43-46.

Dobson, P.; Waterson, M.; Davies, S.W. (2003): The patterns and implications of increasing concentration, in: European food retailing, Journal of Agricultural Economics, Vol. 54 No $1,111-125$

Dobson. P.; Waterson, M. (1999): Retailer power: how regulators should respond to greater concentration in retailing, in: Economic Policy, Vol. 28, No 2, pp. 134-156.

Fernie, J. (1998): The breaking of the fourth wave: recent out-of-town retail developments in Britain, in: International Review of Retail, Distribution and Consumer Research, Vol. 8, No 3, No, pp. 303-17. 
Guy, C.M. (1998a): Controlling new retail spaces: the impress of planning policies in western Europe, in: Urban Studies, Vol. 35 No 5-6, pp. 953-979.

Guy, C.M. (1998b): High street retailing in off-centre retail parks: a review of the effectiveness of land use planning policies, in: Town Planning Review, Vol. 69, No 3, pp. 291-313.

Guy, C.M. (2002): Is retail planning policy effective? The case of very large store development in the UK', in: Planning Theory and Practice, Vol. 3, No 3, pp. 319-330.

Guy, C.M. (2007a): Planning for Retail Development, Abingdon: Routledge.

Guy, C.M. (2010):

Guy, C.M.; Bennison, D. (2002): Retail planning policy, superstore development and retailer competition, in: International Journal of Retail and Distribution Management, Vol. 30, No 9, pp. 431-4.

Guy, C.M.; Bennison, D. (2002): Retail planning policy, superstore development and retailer competition, in: International Journal of Retail and Distribution Management, Vol. 30, No 8, pp. 431-434.

Hallsworth, A. (1994): The decentralization of retailing in Britain - the breaking of the third wave, in: Professional Geographer, Vol. 46, No 3, pp. 296-307.

Hughes, R.; Hallsworth, A. G.; Clarke, G. (2009): Testing the effectiveness of the proposed UK 'competition test', in: Service Industries Journal, Vol. 29, No 5, pp. 569-590.

Humby, C.; Hunt, H.; Phillips, T. (2003): Scoring Points: how Tesco is winning customer loyalty, London: Kogan Page.

Marsden, T.; Harrison, M.; Flynn, A. (1998): Creating competitive space: exploring the social and political maintenance of retail power, in: Environment and Planning A, Vol. 30, No 3, pp. 481-498.

Mintel (2008): E-Commerce - Europe. Retail Intelligence. London: Mintel.

Mintel (2009): UK Retail Rankings 2009. London: Mintel.

Mintel (2010): European Retail Handbook 2009/10. 13th Edition. London: Mintel. 
MMC (Monopolies and Mergers Commission) (1981): Discounts to Retailers, London, HMSO.

OFT (Office of Fair Trading) (1985): Competition and Retailing, London, OFT.

Pal, J.; Bennison, D.; Clarke, I.; Byrom, J. (2001): Power, policy networks and planning: the involvement of major grocery retailers in the formulation of Planning Policy Guidance Note 6 since 1988, in: International Review of Retail Distribution and Consumer Research, Vol. 11, No 3, pp. 225-46.

Reynolds, J.; Howard, E.; Dragun, D.; Rosewell, B.; Ormerod, P. (2005): Assessing the Productivity of the UK Retail Sector, in: International Review of Retail, Distribution and Consumer Research, Vol. 15, No 3, pp. 237-280.

Schiller, R. (1986): Retail decentralisation: the coming of the third wave, in: The Planner, Vol. 72, No 7, pp. 13-15.

Seth, A.; Randall, G. (2005): Supermarket Wars, Palgrave MacMillan: Basingstoke. (Ch.4, Tesco: Chasing Hard)

Smith, A. P.; Sparks, L. (2004): 'All about Eve?’ in: Journal of Marketing Management, Vol. 20, No 3-4, pp. 363-385.

Smith, D.; Sparks, L. (2009): Tesco's supply chain management, in: Fernie, J.; Sparks, L. (eds.): Logistics \& Retail Management: Emerging Issues and New Challenges in the Retail Supply Chain, London and Philadelphia: Kogan Page, pp. 143-171.

Sparks L. (2002): The findings have surprised some shoppers, in: International Journal of Retail and Distribution Management, Vol. 30, No 2, 126-133.

Sparks, L, (1987): Retailing in enterprise zones: the example of Swansea, in: Regional Studies, Vol. 21, No 1, pp. 37-42.

Sparks, L. (2005): Editorial - Special Issue: Assessing Retail Productivity, in: International Review of Retail, Distribution and Consumer Research, Vol. 15, No 3, pp. 227-236.

Sparks, L. (2008a): Retail Regulation, Performance and Supplier Relationships in the United Kingdom, in: Colla, E. (ed): Réglementation et Commerce en Europe: Les effets de la 
réglementation sur les stratégies et les performances des entreprises, Paris: Vuibert, pp. $31-56$.

Sparks, L. (2008b): TESCO: Every Little Helps, in: Usui, K. (ed.) The History of Top Retailers in Europe. Tokyo: Dhobunkun (published in Japanese), pp. 51-81.

Thomas, C.J. (2006): New 'high streets' in the suburbs? The growing competitive impact of evolving retail parks, in: International Review of Retail Distribution and Consumer Research, Vol. 16, No 1, pp. 43-68.

Wood, S.; Lowe, M.; Wrigley, N. (2006): Life after PPG6: recent food retailer responses to planning regulation tightening, in: International Review of Retail, Distribution and Consumer Research, Vol. 16, No 1, pp. 23-41.

Wrigley, N. (1991): Is the 'Golden Age' of British grocery retailing at a watershed?, in: Environment and Planning A, Vol. 23, No 11, pp. 1537-1544.

Wrigley, N. (1992a): Sunk capital, the property crisis, and the restructuring of British food retailing, in: Environment and Planning A, Vol. 24, No 11, pp. 1521-1530.

Wrigley, N. (1992b): Antitrust regulation and the restructuring of grocery retailing in Britain, Environment and Planning A, Vol. 24, No 5, pp. 727-749.

Wrigley, N. (1993): Abuses of Market Power - further reflections on UK food retailing and the regulatory state, in: Environment and Planning A, Vol. 25, pp. 1545-1552.

Wrigley, N. (1994): After the store wars: towards a new era of competition in UK food retailing?, in: Journal of Retailing and Consumer Services, Vol. 1, No 1, pp. 5-20.

Wrigley, N. (1998a): Understanding store development programmes in post-property-crisis UK food retailing, in: Environment and Planning A, Vol. 30, pp. 15-35.

Wrigley, N. (1998b): PPG6 and the contemporary UK food store development dynamic, in: British Food Journal, Vol. 100, No 3, pp. 154-161.

Wrigley, N.; Branson, J.; Murdock, A., Clarke, A. (2009): Extending the Competition Commission's findings on entry and exit of small stores in British high streets: implications for competition and planning policy, Environment and Planning A, Vol. 41, pp. 2063-2085. 